\title{
ADOPTING THE THEORY OF PATTERNS OF COHESION TO ASSESS THE STUDENTS' EXTENSIVE WRITING: DOES IT WORK?
}

\section{A Case Study Towards An Attempt to Design A Practical Analytic Scoring Guide}

\author{
Saudin \\ Politeknik Negeri Bandung \\ saudin@polban.ac.id
}

\begin{abstract}
The study investigated the extensive writing performance of the students across three proficiency levels of English: Advanced, Intermediate and Elementary. From each level, three students were selected purposively to represent high-, middle- and lowachievers. Their nine pieces of writing were then assessed by means of the theory of patterns of cohesion (Halliday and Matthiessen, 2004; Eggins, 2004; Paltridge, 2006; Salkie, 1995; and Gerot \& Wignell, 1994). The patterns consist of five cohesive devices: reference, conjunction, lexical cohesion, ellipsis and substitution. The assessment focused on analyzing the students' failures in observing the patterns. The study, therefore, resembles an error analysis but adopts the cohesive devices, instead of linguistic/ grammatical classifications or other kinds of taxonomy as the sources of errors. As such, the study is the first that introduced the uses the devices as the sources of errors. Further, the errors made by the learners were calculated and compared with the total number of the words they wrote in their essay writing. This way, the data concerning the frequency of the failures in the cohesive devices across the students' levels were obtained, tabulated and then discussed. Based on the results, a model of an analytic scoring guide was proposed to be used for assessing the students' writing performance by considering the differences of levels. The model is expected to be useful for writing teachers as it has a higher level of practicality and measurability compared with other available analytic scoring methods.
\end{abstract}

Key words: extensive writing, analytic scoring guide, cohesion, cohesive devices, error analysis, taxonomy.

\section{Introduction}

Writing is the most difficult aspect to master for not only students but also teachers (Alwasilah, 2007: 47-48 \& Mukminatien, 1991: 1). On the part of the teachers, most of them are not skillful at writing. Research said that in 1980-1985 around 50\% of the faculty members (including school teachers) never published textbooks or articles in Indonesia, let alone in English (Alwasilah, 2010: 11). As for the learners, it goes without saying that writing is not their favorite activity. Every educated child in developed countries learns the rudiments of writing in his or her native language, but very few learn to express themselves clearly with 
logical, well developed organization that accomplishes an intended purpose (Brown, 2004: 218). Therefore, it comes as no surprise that only very few students too in Indonesia could write properly in Bahasa, let alone in English (Lengkanawati, 1990: ii).

The difficulties of writing faced by the students to write are related to some factors. The factors as indicated by Weigle (2002: 5) are the learners' lack of critical thinking (e.g. necessity of evidentiary support for a statement), of knowledge about the language abilities or conventions of language (e.g. style, accuracy/grammatical structure and mechanics), and of content (e.g. background knowledge of the topic they are writing, including the vocabulary related to the topic) and organization.

For this organization, learners need to know the knowledge about the writing conventions to put together their ideas logically. In writing, for example, they should understand what a thesis statement and topic sentence are, including what their functions are, how they make an appropriate outline and a good paragraph, and how they relate one paragraph to the others to cohere, and so on. As for Alwasilah (2007: 5-6), he believes that the learners' problems to write are because they have lack of practice. The knowledge of theories of writing does not guarantee someone to have a good writing skill: what is needed is practice which will certainly take a long process.

Similarly, the intricacies of teaching writing are also to be encountered by writing teachers. The teaching of writing entails demanding additional tasks. Besides preparation for it, teachers still have extra work after the teaching is over. They are supposed to read the students' writing pieces, to give feedback and so forth to help the students with their writing. Apart from whether feedback is beneficial or not to the students, this feedback, which is expected to be given by the learners, is also difficult for teachers to carry out. Though the students seem to have done the writing at their best and exerted much - if not all - of their knowledge of the world and language in their mind to write, mostly their writing is unsatisfactory to the teachers.

Teachers find it difficult to identify what the essay of the students is all about although it has a title. There are too many ideas in it. Some overlap. Others seem to have no relations, or are not elaborated sufficiently. To make matters worse, the teacher oftentimes finds complicated erroneous language structures as some inaccuracies are at once involved in the structures. To find an analogy, it is just like diseases which have been complicated, so it is difficult to determine from where the cure or correction is started. Also, as indicated by Nadjmuddin et al. (2000: 28), it is possible that teachers find the rare uses of cohesive devices such as references and conjunctions and when they are used, the uses are not accurate so that 
the relations among ideas are vague. Therefore, it is not a surprise that the demanding job of teaching writing has occupied the attention of papers, articles, dissertations, books, and even separate journal exclusively devoted to writing in a second language (Brown, 2004: 218).

From the explanation of the intricacies involved in the teaching and learning of writing mentioned above, it follows logically that a test of writing is not a simple task too. This test of writing according to Weigle (2002: 2) involves at least two basic components: instructions that tell test takers what to write, namely, writing performance, and a means of evaluating or assessing the writing samples the test takers produce, that is, a scoring guide or method.

To assess the students' writing by applying a certain treatment of assessment (scoring method), we first need to know what type of writing performance a writing belongs to. There have been so far four types of writing performance: imitative, intensive/controlled, responsive, and extensive writing. However, only extensive writing is discussed in this study since the learners' writing performance investigated belongs to the type (see Brown, 2004: 220 for detailed explanations and differences of the other types of writing performance).

Extensive writing is a writing production that implies successful management of all the processes and strategies of writing for all purposes, up to the length of an essay, a term paper, a major research project report, or even a thesis and dissertation. Writers focus on achieving a purpose, organizing and developing ideas logically, using details to support or illustrate ideas, demonstrating syntactic and lexical variety, and in many cases, engaging in the process of multiple drafts to achieve a final product. At this stage, all the rules of effective writing come into play, and the second language writer is expected to meet all the standards applied to native language writers (Brown, 2004: 220).

Furthermore, the extensive writing performance belongs to the category a timed impromptu test (p. 238). The category implies that test-takers do the writing under a certain time limit to come up with the product and are not able to prepare ahead of time for the topic that will appear. Weigle (2002: 58-9) refers to this probably best researched test type as a direct test of writing in which test-takers actually produce a sample of writing, in contrast with the so-called indirect test of writing - most often, multiple-choice tests of grammar and usage, tests in the forms of picture-cued tasks and picture-cued story sequence, which are usually given to test-takers to produce their imitative and intensive/controlled writing performance.

Now, concerning the treatment of assessment, three treatments, more commonly called scoring methods or scoring scales, are available to assess the extensive writing 
performance although the scoring scales can also be adopted to evaluate the responsive writing. They are known as primary trait, holistic and analytic scoring scales. They are largescale writing tests, tests of writing beyond the level of the individual classroom (Weigle, 2002: 58). Detailed elaborations of the three types of scoring scales are provided with by Weigle (2002: Chapter 6) and Brown (2004: 241- 6). In the following section, only analytic scoring scale is discussed as it is a model of this scoring scale that is trying to be developed in the study.

\section{Literature Review}

In analytic scoring, scripts or writing texts are rated on several aspects of writing or criteria rather than given a single score. Depending on the purpose of the assessment, the writing might be rated on such features (5 - 7 areas) as content, organization, cohesion, register, vocabulary, grammar, or mechanics. This analytic scoring schemes provide more detail information, about a test-taker performance in different aspects of writing and are for this reason preferred over holistic (and primary trait) schemes by many writing specialists (Weigle, 2002: 114 - 115). Further, analytic scoring guide is said to serve best classroom evaluation of writing and offers writers a little more washback than a single holistic or primary trait score; scores in five or six/seven major elements will help to call the writers' attention to areas of needed improvement (Brown: 2004: 246). Thus, this scoring guide provides valuable diagnostic information to teachers and test-takers (Weigle, 2002: 115).

One model of the best known and most widely used analytic scoring scales in ESL was created by Jacobs et al. (1981). In this model of scale, learners' performance is rated on five aspects of writing: content, organization, vocabulary, language use and mechanics. The five aspects are differentially weighed, for example content gets 30 points, language use 25 points, organization and vocabulary respectively 20 points, and mechanics 5 points. The second model was developed for the Test in English for Educational Purposes (TEEP) by Cyril Weir (1988). Instead of five, Weir's scheme consists of seven aspects (content, organization, cohesion, vocabulary, grammar, punctuation, and spelling), each of which is divided into four scales with the score points ranging from 0 to 3 . The third model of an analytic scoring guide is the Michigan Writing Assessment Scoring Guide (Hamp-Lyons, 
1990 \& 1991) for grading an entry-level university writing examination. This scoring guide has three rating scales or aspects to assess: (1) Ideas and Arguments, (2) Rhetorical Features, and (3) Language Control. Like in the TEEP, each aspect is divided. But this time, there are six divisions of scales having the score points from 1 (the lowest) to 6 (the highest). The access to all these three scoring guides can be gained through Weigle's (2002: 116 - 119) book.

Providing more detail information, this analytic scoring, however, has several disadvantages. Its major disadvantage is that it takes time for assessing the learners' writing performance so that its practicality is low because much time is needed to attend to details within each of categories or scales in order to come up with a final score or grade (see: Weigle, 2002: 120 \& Brown 2004: 246). Other criticisms of analytic scoring point out that the criteria used in describing how each aspect or scale can be achieved by writers are vague and indefinable (Weigle, 2002: 119). For these reasons, current scholarship (e.g. Weir, 1990; Hamp-Lyons, 1990; Bachman and Palmer, 1996) emphasize the need for clearly defined criteria and well-articulated levels for each scale within an analytic scoring guide.

This article is aimed at offering a model of analytic scoring scales (including their criteria) which are practical (therefore time saving) and measurable (definable and not vague). The development of the scales is of critical importance for the validity of the assessment. As McNamara (1996) notes, the scales that are used in assessing performance tasks such as writing tests "represents, implicitly or explicitly, the theoretical basis upon which the test is founded; that is, it embodies the test (or scale) developer's notion of what skills or abilities are being measured by the test".

To achieve these properties of practicality and measurability, the learners' extensive writing performance was assessed by using patterns of cohesion (Halliday and Matthiessen, 2004; Eggins, 2004; Paltridge, 2006; Salkie, 1995; and Gerot \& Wignell, 1994). These patterns of cohesion are one of the discussions found in the Systemic Functional Grammar (SFG), which is associated with a social semiotic linguist Michael Halliday. That is a theory of language explaining how texts work, describing language in actual use, and focusing on texts and their contexts (Gerot \& Wignell, 1994). The theory views grammar not as a set of rules to master but as that of systems containing language resources or patterns to choose from in order to make meaning appropriately (cf. Emilia, 2005).

Cohesion is defined as the way how the elements within a text bind it together as 'a unified whole": "There has to be cohesion if meanings are to be exchanged at all" (Halliday and Hasan, 1976: 300). Further, Halliday and Hasan (1985: 48) state that cohesion is an 
important contribution to coherence. The statement is supported by other linguists such as Liu (2000 cited in Paltridge, 2006: 152) as saying "coherence is very hard to achieve in a text if it does not, in the first place, have cohesion". Though there are some other factors informing a coherent text such as its identifiable genre, it is concluded that cohesion represented by its most frequently used device, namely lexical cohesion, that becomes the predominant mode of a coherent text (Hoey, 1991 in Angermeyer, 2002: 363; see also Meisuo, 2000; Liu and Braine, 2005 in Alarcon and Morales, 2011; and Saudin, 2013).

Since coherence is contributed by cohesion as indicated by the linguists above, the adoption of cohesion indirectly includes that of coherence. In order words, the use of cohesion in this paper-based research to assess the quality of a writing performance includes that of coherence to a certain extent. As cohesion and coherence, known as texture, are responsible for a text to be well-known/outstanding and to have the quality of being a text (Celce-Murcia and Olshtain, 2000; and Bloor and Bloor, 2004), assessing the quality of a text based on cohesion is therefore feasible and worth attempting.

Cohesion has lexico-grammatical patterns that consist of 5 cohesive resources/devices known as Patterns of Cohesion. They are (1) identification/ reference: Identification/ reference serves to make sense of discourse (Martin \& Rose, 2007: 156) since reference enables us to keep track of who or what is being talked about at any point; (2) lexical cohesion, a concept that there are certain expectancy relations between words to co-occur; (3) conjunctions which Martin \& Rose (2003: 116) call the logic of discourse, the logical meanings that link activities and messages in sequences; (4) substitution (the omission of a word, a phrase or even a clause instead of repeating it); and (5) ellipsis (the use of general words in English like one, do and so to replace words that have already been used). Detailed information regarding these cohesive devices can be obtained in the books written by the linguists already mentioned in the previous three paragraphs. Below are further explanations of the three main devices.

Eggins (2004: 33) says, "we certainly will have no trouble making sense of a text if it contains the three main cohesive resources in written language: reference, lexical cohesion and conjunction, which are exploited with great craft." Eggins lists three commonest presuming reference items. They are $\{1\}$ the definite article, the, $\{2\}$ demonstrative pronouns, namely this, that, these, those, $\{3\}$ personal pronouns, for example. he, she, it, they, mine, his, hers, theirs, himself. However, in her model of referential analysis (p. 38), she includes relative pronouns as presuming reference items. For this reason, relative pronouns such as who, which, and whose are included as reference items. 
Conjunctions refers to how the writer creates and expresses logical relationship between the parts of a text to establish semantic unity that characterizes meaningful structures and unproblematic text (Eggins, 2004: 47). The logical relationships established by this cohesive resource are such as causal (reason, consequence, and purpose), conditional, temporal, additive, elaboration (including exemplification and rewording), and adversativelconcessive. The sentence But now, just few students join the class can only be fully interpreted if we read it in a contrastive logical relation with a sentence such as Last meeting the class was crowded.

Concerning the cohesive resource of lexical cohesion, Eggins (2004) refers it as a concept that there are certain expectancy relations between words, meaning that certain words have tendency to co-occur because they have syntagmatic relations among themselves in creating a clause, just like letters among themselves in forming a word. It is also said that those relations can be in the forms of repetition (e.g. words repeated even though they are inflected for tense, number etc.), antonymy (opposite or contrastive meaning); synonymy (words which are similar in meaning); hyponymy (classes of lexical items where the relationship between them is one of 'general-specific' or 'class/super-ordinate to member' type, e.g. agricultural products: rice, paprika etc.; meronymy (classes of words where the relationship between them is of a 'whole-part', e.g. a car: door, dashboard etc.; related words (words such as tour and holiday, along with dentists, injections, and nervous which "are hard to say precisely what the relationship between the words is, but it is clear that they come from the same general area of vocabulary and that they help the text to cohere" (Salkie, 1995: 28); and lastly collocation, word partnership, which makes a predictable and naturally-sounding pairing or combination (Lewis, 1997: 51 in Avci, 2006: 24) and syntactically consists of adj-n, v-n, nprep, n-n and so forth (see Yan, 2010; and Mahvelati \& Mukundan, 2012 for the exhaustive list).

\section{Methodology}

The extensive writing performance was assessed by the application of the theory of patterns of cohesion. The assessment centered on the errors the learners made when employing cohesive devices. As such, this study can be included as an error analysis, which usually analyzes learners' errors classified into some metalanguage criteria or certain grammatical categories. In this kind of research, errors are analyzed and put into some domains such as wrong order and use of words, wrong tense and verb form, wrong subject verb agreement, 
wrong use of articles and prepositions, sentence fragments and run-on sentences (see Paster, 1986; Michaeldes, 1990; Chen, 2000; Chen, 2006; and Lin, 2002); and the domains are oftentimes further classified into broader categories: negative interlingual and intralingual transfer as proposed by Richards (1974) and supported by Ellis (1994: 58-59; Schachter and Celce-Murcia, 1977; and Ferris, 2002: 5).

Different from the previous studies above, this present study adopted cohesive devices namely reference, conjunction, ellipsis and substitution (all known as grammatical cohesion) and lexical cohesion as the domains of errors. To the best of the researcher's knowledge, little or even no work on error analysis has even been related to the erroneous employment of these cohesive devices. This paper-based research, therefore, attempted to fill the gap by offering the devices to be the sources of the learners' errors with the purposes of designing a practical analytic scoring guide and suggesting the central roles of the devices to determine a sensible and unproblematic text as already elaborated in the literary review.

The extensive writing performance, as corpus of this study, was taken from three classes. The first one was a class of Advanced-4 students tested to be able to complete their course in one big and long-established English-teaching institution in Bandung. The second one was a class of Intermediate- 4 students who took the test in order that they could be promoted to Advanced level. And the last one was a class of Elementary-4 students who followed the promotion test to be placed in the Intermediate class. In the tests, they were supposed to write one of three topics provided with writing prompts by using 350-450 words for Advanced, 150-200 words for Intermediate, and 100-150 words for Elementary level. Out of 13 students of Advanced, 17 of Intermediate and 10 of Elementary level (most of them are Senior High School students), three were selected purposively from their respective levels to represent low-, middle-, and high-achiever students.

This research is qualitative in nature despite the use of some tables presenting numerical data. The qualitative method was used for in-depth analysis of the students' writing tests to obtain broad explanatory information about the phenomenon under study, that is, the learners' failures in realizing the cohesive devices of the patterns of cohesion in their writing performance. Numerical data, which are considered as one of the criteria of quantitative method, just illustrated the profiles of the students' failures in observing the patterns of cohesion. Creswell (1994) says it is possible to use a combination of these two methods as one method can support the other one by means of elaborating, enhancing or illustrating the results from the other method. In other words, quantitative method was subsidiary to qualitative one in this paper-based study. 
A case study design has been chosen in this research because the design allows the researcher to study the phenomenon deeply to find meaning behind it as Connole (1993: 64 cited in Emilia, 2009: 5) says: "the essential feature of a case study is the level of depth it can offer in researching all illustrative examples of some phenomenon." Creswell (2007: 73) defines case study research as a qualitative approach in which the investigator explores a bounded system (a case), or multiple bounded systems (cases) over time through detailed, in depth data collection involving multiple sources of information such as documents.

\section{Data Analysis}

The students writing tests (nine pieces altogether, respectively three from the Advanced, Intermediate and Elementary students) were analyzed following the model of text analysis suggested by Fairclough (2003: 89-97). However, instead of labeling the part of the text based on the right uses of cohesive resources, this paper-based research labels the erroneous applications of the resources. It is also necessary to note that once in a while, an error in conforming to a cohesive device (lexical cohesion, especially) involves complex lexical items. Though complex, they are treated as a single erroneous application of cohesive device since they operate to encode one meaning. This procedure is in line with what Eggins (2004: 44) has suggested.

Concerning labeling, it is a common practice both in SFG (Systemic Functional Grammar) and error analysis. Halliday and Matthiessen (2004) and Eggins (2004) have instantiated the uses of labels in SFG's text analyses, which also support errors analysis, as seen from the assertion that a text analysis should contain an evaluation of the text which "may enable one to say why the text is, or is not, an effective text for its own purposes - in what respects it succeeds and in what respects it fails, or is less successful" (Halliday' 1994: xv in Eggins, 2004: 329). Labels are also employed in the investigation of students' errors (see Ellis, 1994: 55-56). Therefore, the labeling of the erroneous use of cohesive devices adopted in this study is theoretically valid.

The following part is aimed to show how the cohesive devices from the theory of patterns of cohesion are implemented in analyzing or evaluating the students' writing tests. The analyses are conducted on some parts of the piece written by one student of Advanced level with the category of middle achiever.

(1) Although its price is LEX. COHESION compare with its features, so ELLIPSIS does the LEX. COHESION price's of maintenance. Don't you know that new 
technology with the new features also LEX. COHESION have more attention? Usually, new features are so useful but more sensitive, so that we must control and update REFERENCE it CONJUNCTION whether not, the pay for the maintenance can be expensive as that LEX. COHESION [for the] technology ...

(2) ... it'll LEX. COHESION make some bad influences LEX. COHESION to our eyes and brain for example LEX. COHESION eyes radiation or maybe brain cancer.

This learner, in the first example, failed 4 times in realizing the device of lexical cohesion. In the first three, the failures happened because the three lexical items underlined were erroneously chosen. The item compare should have been written comparable to establish a relation as expected in the lexical environment where the item was used. For the purpose of also establishing this expectancy relation with other lexical items within one environment, the items price's should have been replaced by price and the wrongly used plural verb have by the singular verb requires/needs. In the last failure, the learner failed to come up with the writing of the two lexical items in the square brackets [for the] in order to relate the word technology with others in an expected and meaningful way.

In addition to the four failures in lexical cohesion, the learner employed ellipsis, reference and conjunction erroneously. In the case of ellipsis, instead of does, he was expected to use is in such lexical environment. Further, he should have written the reference item them instead of it since the antecedent of the reference item is plural, that is, new features. Lastly, the learner failed to use a conjunction. He was supposed to apply a conditional conjunction if, not an alternation type whether, in order to make the meaning accessible.

In the second example, the same learner made errors in realizing collocation alone, a major member of lexical cohesion, of which the use represents the most frequent errors in this research. First, he failed in forming v-n collocation. The learner wrongly collocated the process make, instead of have, with the lexical item influence. Second, the failure concerned n-prep collocation. He should have used the preposition on, not to, with the item influence to create a natural sounding word combination influence on. Lastly, He was also unable to create a sensible n-n collocation when realizing the group eyes radiation, which should say eye radiation.

To provide the linguistic evidence of the non-observance of cohesive devices conducted by the learners of the other two levels, their sentences are presented below.

(1) You can buy everything LEX. COHESION that what you want, but ... (Written by the middle achiever of Intermediate level) 
(2) ... this film LEX. COHESION showing modern cars, LEX. COHESION [it is] very amazing. (Written by the low achievers of the Elementary level)

In the first linguistic evidence, the middle achiever of Intermediate level failed to notice that the two lexical items that and what are not expected to co-occur within one lexical environment. It is either one or the other that could be used in such a sentence. The learner, therefore, should have written either You could buy what you want or You could buy everything that you want. In the second evidence, two unsuccessful attempts of realizing lexical cohesion were made by the low achiever of Elementary level. First, the learner did not realize that the finite verb shows is expected to be used in that lexical environment instead of the non-finite showing to form a timeless present tense. Second, the learners was also unable to see the need for the provision of two lexical items it is to precede the group very amazing to establish an expectancy relation between the group and the two items to create a clause.

\section{Findings and Discussion}

To start with, it is necessary to present the overall picture of the data derived from all the analyses which have been conducted in the Appendix. For the purpose of making them clearly seen and easily discussed, the data are displayed in just one table, that is, Table 1. As seen, the table shows the distributions of the Advanced, Intermediate and Elementary students' failures in observing the cohesive devices related to reference, conjunction, lexical cohesion, and ellipsis/substitution. All the data in the table are put under the heading of the profiles of the students' failures in observing the cohesive devices across the three levels.

Referring to the data of how the cohesive devices were not observed as depicted in the first through the fourth row, it is seen clearly that lexical cohesion is the most frequent type of errors or failures. The total number of errors made by all the learners in this device was 215 , far above that of errors in reference, conjunction and ellipsis/substitution with the totals of 18,3 and 1 respectively.

This overwhelming predominance of errors in lexical cohesion results from several factors. The first one is that lexical cohesion has been widely acknowledged as the most frequently used cohesive device (Meisuo, 2000 in Alarcon \& Morales, 2011: 116-117; Liu and Braine, 2005; Hoey, 1991 in Angermeyer 2002: 364; Saudin, 2013). Even lexical cohesion, not reference has been proposed to be mentioned first in the order of how the cohesive devices are sequenced in the theory of patterns of cohesion (Saudin, 2013: iii). The 
first mention of reference is misleading, causing us to think it is reference not lexical cohesion that is the most frequently used device. As the real most frequent device employed, lexical cohesion naturally also represents the main source of errors made by the learners as revealed in this study.

Table 1

Profiles of the Students' Failures in Observing Patterns of Cohesion Across Three Proficiency Levels

\begin{tabular}{|c|c|c|c|c|c|c|c|c|c|}
\hline \multirow{2}{*}{$\begin{array}{c}\text { Cohsv } \\
\text { Dves }\end{array}$} & \multicolumn{3}{|c|}{ Advanced } & \multicolumn{3}{|c|}{ Intermediate } & \multicolumn{3}{|c|}{ Elementary } \\
\hline & High & Mid & Low & High & Mid & Low & High & Mid & Low \\
\hline Ref. & 1 & 5 & 3 & 2 & 0 & 0 & 1 & 4 & 2 \\
\hline Conj. & 0 & 1 & 0 & 0 & 0 & 0 & 0 & 2 & 0 \\
\hline $\begin{array}{l}\text { Lex. } \\
\text { Chsn }\end{array}$ & 18 & 35 & 41 & 10 & 13 & 28 & 25 & 14 & 31 \\
\hline $\begin{array}{l}\text { Ellip./ } \\
\text { subst. }\end{array}$ & 0 & 1 & 0 & 0 & 0 & 0 & 0 & 0 & 0 \\
\hline $\begin{array}{l}\text { Total } \\
\text { Fails. } \\
\& \%\end{array}$ & $\begin{array}{c}19 \\
5.6 \%\end{array}$ & $\begin{array}{c}42 \\
8.6 \%\end{array}$ & $\begin{array}{c}44 \\
14.1 \%\end{array}$ & $\begin{array}{l}12 \\
7 \%\end{array}$ & $\begin{array}{c}13 \\
9.3 \%\end{array}$ & $\begin{array}{c}28 \\
18.5 \%\end{array}$ & $\begin{array}{c}26 \\
11.4 \%\end{array}$ & $\begin{array}{c}20 \\
18.5 \%\end{array}$ & $\begin{array}{c}33 \\
31.7 \\
\%\end{array}$ \\
\hline $\begin{array}{l}\text { \# wrds } \\
\text { written }\end{array}$ & 340 & 487 & 311 & 171 & 140 & 151 & 227 & 108 & 104 \\
\hline $\begin{array}{l}\text { freq. of } \\
\text { fails. }\end{array}$ & $\begin{array}{c}1 \\
\text { evry } \\
17-18 \\
\text { words }\end{array}$ & $\begin{array}{l}1 \text { evry } \\
11-12 \\
\text { words }\end{array}$ & $\begin{array}{c}1 \text { evry } \\
7 \\
\text { words }\end{array}$ & $\begin{array}{l}1 \text { evry } \\
14-15 \\
\text { words }\end{array}$ & $\begin{array}{l}1 \text { evry } \\
10-11 \\
\text { words }\end{array}$ & $\begin{array}{c}1 \text { evry } \\
5-6 \\
\text { words }\end{array}$ & $\begin{array}{c}1 \text { evry } \\
8-9 \\
\text { words }\end{array}$ & $\begin{array}{c}1 \text { evry } \\
5-6 \\
\text { words }\end{array}$ & $\begin{array}{c}1 \\
\text { evry } \\
3-4 \\
\text { Words }\end{array}$ \\
\hline
\end{tabular}

The second factor is the inclusion of errors in some linguistic classifications to be as those in lexical cohesion. As already demonstrated in the section of data analysis, the failures in exploiting the device do not just include the erroneous realizations of collocation. The scopes of failures in the device also cover the wrong use of word, the fourth main source of errors (Lin, 2002); wrong verb form, reported to be the second main source of errors (Lin, 2002; Paster, 1986; and Horney, 1998 in Chen, 2006); the most frequent error (Angwatanakul, 1980); and wrong use of tense, the most frequent errors (Paster, 1986; and Chen, 1998).

The last factor is that failures in lexical cohesion even include those related to mechanics. Errors in spelling and capitalization for example are considered to be failures in lexical cohesion. This is in line with Eggins (2004, 191-192), who suggests that letters have syntagmatic relations among themselves in forming a word, just like words among themselves in creating a clause. In other words, when mechanical errors happen - just like 
when failures in using lexical items do - then expectancy relation, the general idea behind lexical cohesion, is disturbed. In short, it is not then something unpredictable that erroneous employment of lexical cohesion overwhelmingly exceeds that of the other cohesive devices. As for reference, the fact that the device holds the second most frequent failures, leaving conjunction and ellipsis/substitution behind, is not something beyond the expectation too. It is said that errors in English articles were the highest (Horney, 1998 in Chen, 2006), frequently found among Taiwanese EFL students (Chen 2000 in Chen 2006), and one of the most predominantly made among Thai English learners (Angwatanakul, 1980; Michaeldes, 1990 cited all in Sattayatham \& Honsa Jr. 2007).

Next, the total number of the wrong use of conjunction is behind that of the failures in using lexical cohesion and reference. That is again not something unexpected. Among the studies on error analysis, only one conducted by Sattayatham \& Honsa Jr. (2007) mentioned it as a source of errors. Lastly, it was errors in ellipsis and substitution that were the least. This does not come unexpectedly, considering that the uses of ellipsis and substitution is a characteristic of question and answer or similar adjacency pairs in dialogue (Halliday and Matthiessen, 2004: 536). The texts investigated in this paper-based research are of a written mode which is non-dialogic in nature. Therefore, the two devices were infrequently realized and their errors were accordingly rare.

The most robust support to the order of appearances of the devices in terms of their wrong uses as elaborated above comes from the study conducted by Saudin (2013). In the study, the cohesive devices were investigated in two respects: the deployment and erroneous employment of the devices. In that research, the order of appearances of the devices, if they were not expanded to cover other devices, are not different from that of their appearances in this present study. The lexical cohesion comes first, then reference, conjunction and ellipsis/substitution appear one after another.

Now, after discussing the findings displayed in first through the fourth row to compare them with those reported by other similar studies, here the discussion of the proposed practical scoring guide comes. This time, the findings taken into account to propose the scoring guide are ones illustrated in the last row. Those are the frequencies of failures performed by the learners across the three proficiency levels.

As shown in the last row of Table 1, the findings reveal that the frequencies of failures committed by the students of the same level are different when they are in the same category. The higher their categories is, the less the failures they performed. For example, the student of Advanced level categorized into the high achiever failed just one every 17-18 words 
(5.6\%), while the student of the same level classified as the middle achiever one every 11-12 $(8.6 \%)$ and the student of the same level categorized into low achiever one every $7(14.1 \%)$.

The findings also suggest that the Advanced, Intermediate and Elementary students when they are in the same category (e.g. high achiever) have different profiles of failures in observing the cohesive devices. For instance, the Advanced student categorized into the high achiever failed one every $17-18$ words $(5.6 \%)$, the Intermediate learner of the same category one every 14-15 words (7\%) and the Elementary learner of the high achiever one every 8-9 words $(11.4 \%)$.

Taken together, the findings of this study suggest that there are distinct and significant discrepancies of frequency of failures in observing the cohesive devices within one proficiency level and across the three proficiency levels when the learners' categories are taken into account. As such, the adoption of cohesive devices as sources of errors to indicate the students' levels of proficiency is feasible although this claim needs to be supported by other future studies. This application of cohesive devices can distinguish strikingly the learners' writing quality just like the adoption of grammatical classifications as sources of errors. It is claimed that more grammatical errors are made as the learners' proficiency (or their category) gets lower (see Witte and Faigley, 1981). Likewise, the more the failures in using cohesive devices are, the lower the learners' proficiency is.

On the one hand, it is said the adoption of linguistic classifications/other taxonomies as sources of learners' errors can be an indicator of learning achievement and guidance for teaching (Dulay, Burt \& Krashen, 1982 in Sattayatham \& Honsa Jr. 2007: 173). On the other hand, it is safely said that the application of cohesive devices can be for that kind of indicator too. Even, this study tries to suggest that the application can be used to propose a design of a more practical analytic scoring guide though tests are needed to prove its feasibility. This design of an analytic scoring guide is seen in Table 2. The model is the result of using the cohesive devices as the indexes of the learners' errors and is derived from the data as presented in the last row of the previous Table 1. 
Table 2

The Proposed Practical Model of Analytic Scoring Guide For ESL/EFL Composition Across Three Proficiency Levels

\begin{tabular}{|l|l|l|}
\hline \multicolumn{1}{|c|}{ Level } & \multicolumn{1}{|c|}{$\begin{array}{c}\text { Scales of frequency of failures in } \\
\text { observing patterns of cohesion }\end{array}$} & \multicolumn{1}{|c|}{ Criteria } \\
\hline \multirow{4}{*}{ Advanced } & 1 every $17-18$ words or more & High achiever \\
\cline { 2 - 3 } & 1 every $11-12$ words & Middle achiever \\
\cline { 2 - 3 } & 1 every 7 words & Low Achiever \\
\hline \multirow{4}{*}{ Intermediate } & 1 every $14-15$ & High achiever \\
\cline { 2 - 3 } & 1 every $10-11$ & Low Achiever \\
\cline { 2 - 3 } & 1 every $5-6$ & High achiever \\
\hline \multirow{5}{*}{ Elementary } & 1 every $8-9$ words & Middle achiever \\
\cline { 2 - 3 } & 1 every $5-6$ words & Achiever \\
\cline { 2 - 3 } & 1 every $3-4$ words & \\
\hline
\end{tabular}

As seen in the very right column, the criteria in this proposed practical analytic scoring guide just refer to the categories of the writers in their respective levels. This way, the criteria are clear and definable, directly indicating the category or proficiency of a certain level one learner belongs to. The criteria are different from those in the other three models proposed respectively by Jacobs et al (1981), Weir (1988) and Hamp-Lyons (1990 \&1991). In these three models, the criteria are descriptive and often long elaborated, making them vague and indefinable, as indicated by Weigle (2002: 119). It is suggested that the criteria used in this proposed model is simple. As a result, they will reduce the amount of time considerably in assessing the writing performance.

Further, the scales in this proposed method as depicted in the middle column are obviously more measurable compared with those of the other three methods. The scales in the former are not based on score ranges of which the discrepancies are wide but on a frequency of calculable failures of the writers in observing patterns of cohesion. For example, if a middle-achiever writer of intermediate level makes a total of 25 failures in his/her composition consisting 250 words altogether, it means he/she (and all other middle achievers of that particular level, accordingly) fall into the scale of the frequency of 10, meaning every ten words written he/she fails once on average in attending to the patterns.

All in all, the model proposed by this present study also reflects the common practice done by writing teachers in assessing their students' writing pieces. In assessing, writing teachers usually circle, underline, or indicate with question mark/other signs the writing parts 
needing to be improved. In the model, instead of being circled or given a certain sign, the writing parts are labeled using the names/types of cohesive devices/resources of the patterns of cohesion the writing fails to observe. In other words, this study just formalizes that common practice by supporting it with underpinning theories.

\section{Conclusions and Suggestions}

In conclusion, the analytic scoring guide proposed above can benefit the writing teachers. As can be seen, it is practical and much less complicated than the other existing three guides as mentioned previously. It has brief scales and criteria - thus making it easy to apply. In addition, to apply the theory of patterns of cohesion in assessing the students' writing performance, teachers may not need any training at all. Moreover, the ways of how failures in the patterns of cohesion are used as the basis of the assessment of writing have actually been practiced by writing teachers widely though they may not have realized it.

To make the scoring method more easily applied, it is necessary for the testadministers to ask the students to count the total number of the words they have written soon after the writing process is over if they have not performed the writing on computers. That way, the teacher rater will further save time considerably in assessing the students' writing performance. The total number of the words is just divided by that of the students' failures in observing the patterns of cohesion.

Another point needs to be noted in applying the proposed model of scoring method to assess writing pieces, though. The point is that one aspect which needs to be scored too, that is, the generic coherence of the text has not been incorporated in the model. Therefore, it is advisable that its genre have been identifiable in the first place before a writing piece is evaluated in order that the model can be used to assess it more reliably since it is believed that a text should have texture, that is, cohesion and coherence in order it meets the quality of being a text. Lastly, while the study reveals interesting findings about the relationship between the learners' failures in cohesive devices and their proficiency - the relationship upon which this proposed practical analytic scoring guide is drawn - these findings may not be generalized beyond the subjects of the study. 


\section{References}

Alarcon, J. B. and Morales, K. N. S. (2011). Grammatical cohesion in students' Argumentative essay. Journal of English and Literature Vol. 2(5), pp. 114 - 127, June 2011. http://www. academicjournals.org/ijel/ PDF/Pdf2011/June/Alarcon\%20and\%20 Morales.pdf

Alwasilah, A. C. (2010). Language, culture, and education: A Portrait of contemporary Indonesia. Bandung: CV Indira.

Alwasilah, A. C. (2007). Pokoknya menulis. Bandung: PT Kiblat Buku Utama.

Angermeyer, P.S. (2002). Lexical cohesion in multilingual conversation. International Journal of Bilingualism. Volume 6, No 4. December 2002, 361-393.

Angwatanakul, S. (1980). Relationships between communicative competence and learning achievement in the English language. Chulalongkorn Educational Review, Chulalongkorn University.

Avci, G.B. (2006). The effects of collocation instruction on writing. Unpublished Dissertation, Istambul Technical University, English Preparatory Programme. [Online]. Available: www.bergeler.com

Bachman, L. F. \& Palmer, A. S. (1996). Language testing in practice. Oxford: Oxford University Press.

Bloor, T. and Bloor, M. (2004). The functional analysis of English. London: Arnold.

Brown, H. D. (2004). Language assessment: Principle and classroom practices. USA: Pearson Education, Inc.

Celce-Murcia, M. and E. Olshtain (2000). Discourse and context in language teaching: A guide for language teachers. Cambridge, Cambridge University Press.

Chen, H. C. (1998). A contrastive analysis of the language errors made by the Chinese students of English as a second/foreign language. Journal of Wu-Feng Applied Linguistics, 6, 224-237.

Chen, H. C. (2000). Error analysis of some features of English article usage. Journal of Wu-Feng Applied Linguistics, 8, 282-296.

Chen, L. L. (2006). The effect of the use of $\mathrm{Li}$ in multimedia tutorial on grammar learning: An error analysis of Taiwanese beginning EFL learners' English essays. EFL Journal, 2006 Vol $8(2)$.

Connole, H. (1993). The research enterprise. In H. Connole, B. Smith \& R. Wiseman (1993). Reseach methodology I: Issues and methods in reseach. A study guide. Melbourne: Deakin University.

Creswell, J. W. (1994). Research design: Qualitative \& quantitative approaches. Thousand Oaks, California: Sage Publications, Inc.

Creswell, J.W. (2007). Qualitative inquiry \& reseach design: Coosing among five approaches $\left(2^{\text {nd }}\right.$ Ed). Thousand Oaks, California: Sage Publication.

Dulay, H., Burt, M. \& Krashen, S.D. (1982). Language two. MA. Rowley: Newbury House

Eggins, S. (2004). An introduction to systemic functional linguistics. London: Continuum International Publishing Group.

Ellis, R. (1994). The study of second language acquisition. Hong Kong: Oxford University Press.

Emilia, E. (2009). Menulis tesis dan disertasi. Bandung: Alfabeta

Emilia, E. (2005). A critical genre-based approach to teaching academic writing in a tertiary EFL context in Indonesia. Volume I. Unpublished Dissertation at Department of Language, Literacy and Arts Education, Faculty of Education, The University of Melbourne.

Fairclough, N. (2003). Analysing discourse: Textual analysis for social research. Great Britain: Routledge. 
Ferris, D. (2002). Treatment of error in second language student writing. USA: Ann Arbon, The University of Michigan Press.

Gerot, L., \&Wignell, P. (1994). Making sense of functional grammar. Australia: Gerd Stabler, Antipodean Education Enterprises

Halliday, M.A.K. \& Hasan, R. (1976). Cohesion in English. London: Longman.

Halliday, M. A. K. (1994). An introduction to functional grammar $2^{\text {nd }}$ Ed. London: Edward Arnold.

Halliday, M.A.K. \& Matthiessen, C. M.I.M. (2004). An introduction to functional grammar $3^{\text {rd }} E d$. Great Britain: Oxford University Press Inc.

Hamp-Lyons, L. (1990). Second language writing: Assessment issues. In B. Kroll (ed.), Second language writing: Research insights for the classroom. New York: Cambridge University Press.

Hoey, M. (1991). Patterns of lexis in text. Oxford: Oxford University Press.

Hornby, AS., Cowie, AP., Gimson, AC. (1983). Oxford advanced learner's dictionary of current English. London: Oxford University Press.

Jacobs, H., Zinkgraf, S., Wormuth, D., Hartfiel, V., \& Hughey, J. (1981). Testing ESL composition: A practical approach. Rowley, MA: Newbury House.

Lengkanawati, N. (1990). Aspek logika dan aspek linguistik dalam ketrampilan menulis: Studi tentang profil komposisi bahasa Indonesia dan bahasa Inggris. Unpublished Master's Thesis. Bandung: UPI.

Lewis, M. (1997). Implementing the lexical approach: Putting theories into practice. London: Language Teaching Publications.

Lin, S. (2002). A case study of English writing competence of students at the Mei Ho Institute of Technology. Journal of Mei Ho Institute of Technology, 20, 180-206.

Liu, D. (2000). Writing cohesion: Using context lexical ties in ESOL. English Teaching Forum, 38, 1, 28-35.

Liu, M. and Braine, G. (2005). Cohesive features in Argumentative writing produced by Chinese undergraduates. [Online]. Available: http://www.sciencedirect. com/science.

Mahvelati, E. H. \& Mukundan, J. (2012). The role of cognitive style in the collocational knowledge development of Iranian EFL learners through input flood treatment. English Language Teaching 5. 10 (2012): 105-117.

Martin J. R.\& Rose, D. (2007). Working with discourse: Meaning beyond the clause $2^{\text {nd }} E d$. Great Britain: Continuum.

McNamara, T. F. (1996). Measuring second language performance. London and New York: Longman.

Meisuo, Z. (2000). Cohesive features in the expository writing of undergraduates in two Chinese univesities. RELC J., 52431(61).

Michaeldes N. N. (1990). Error analysis: An aid to teaching. English Teaching Forum, 28(4), 28-30.

Mukminatien, N. (1991). Developing writing skills by providing interactive experience. Unpublished Master's Thesis. Malang: IKIP Malang.

Nadjmuddin, M., Saudin, H., \& Yuliah, S. (2000). Strategi menulis esei dan analisis struktur retorika teks: Studi kasus mahasiswa Administarsi Niaga. Laporan Riset. Bandung: POLBAN.

Paltridge, B. (2006). Discourse analysis: An introduction. Great Britain: Continuum.

Paster, A.C. (1986). The ILokano ESL learner: A study of interlanguage. M.A. Thesis: National University of Singapore.

Richards, J.C (ed.) (1974). Error analysis: Perspectives on second language acquisition. London: Longman.

Salkie, R. (1995). Text and discourse analysis. London and New York: Routledge. 
Sattayatham, A. \& Honsa, S., Jr. (2007). Medical students' most frequent errors at Mahidol University, Thailand. EFL Journal, Vol. 9, No. 2.

Saudin, H. (2011). Genre-based approach and the students' meaning-making: A case study of students' writing cohesion. In the Proceedings of Eighth conference on English studies: Unika Atmajaya, Jakarta.

Saudin, H. (2013). The realization of cohesion in students' Argumentative writing performance. Unpublished Master Thesis. Indonesia University of Education, Bandung.

Schachter, J. \& Celce-Murcia, M. (1977). Some reservations concerning error analysis. TESOL Quarterly 11: 441-51.

Weigle, S. C. (2002). Assessing writing. UK: Cambridge University Press.

Weir, C. J. (1988). Construct validity. In A. Hughes, D. Porter and C. J. Weir (ed.), ELTS Validation project report (ELTS Research Report 1 (ii)). London: The British Council/ UCLES.

Witte, S. P. and Faigley, L. (1981). Coherence, cohesion, and writing quality. College Composition and Communication, Vol. 32, No. 2 pp. 189-204, Language Studies and Composing.

Yan, H. (2010). Study on the causes and countermeasures of the lexical collocation mistakes in college English. English Language Teaching 3.1 March (2010): 162-165. ProQuest document ID: 839755762 Document URL: http://search. proquest.com/docview/ 839755762 ?accountid $=13567$. 